\title{
Threats to the maleo Macrocephalon maleo and recommendations for its conservation
}

\author{
Gillian C. Baker and Stuart H. M. Butchart
}

\begin{abstract}
The maleo Macrocephalon maleo (Megapodiidae; Galliformes) is a megapode, endemic to Sulawesi, Indonesia, that lays its eggs communally in geothermally or solar-heated soil. The majority of maleo nesting grounds are threatened to some degree and over onethird of known sites have been abandoned. Maleos are severely threatened by habitat degradation and uncontrolled egg-collecting. Hunting of adult birds is also contributing to their decline in some areas. Conservation measures implemented so far have not been sufficiently effective in preventing maleo population declines. In
\end{abstract}

\section{Introduction}

The Indonesian island of Sulawesi is biogeographically fascinating and its fauna is highly distinctive: 98 per cent of non-volant mammals are endemic to the island, as are 27 per cent of bird species, including an exceptional total of 12 endemic genera (Whitten et al., 1987; Coates et al., 1997). The maleo Macrocephalon maleo (Megapodiidae; Galliformes) is one of Sulawesi's most remarkable and well-known endemic birds.

Maleos incubate their eggs at communal nesting grounds where the soil is warmed by solar or geothermal heat. Pairs of adult birds excavate burrows up to $1 \mathrm{~m}$ deep, in which the female lays a single egg. Once the egg has been buried, the adults carry out no further parental care. Maleos forage in montane forest, often several kilometres away from the nesting grounds (Jones et al., 1995). The maleo is threatened by loss of habitat, egg predation and hunting (Dekker, 1990; Argeloo, 1994; Dekker \& McGowan, 1995) and is listed as vulnerable to extinction (Collar et al., 1994; Dekker et al., in press).

The first island-wide assessments of the status and distribution of the maleo were reported by Dekker (1990) and Argeloo (1994) who carried out surveys in

Gillian Baker (corresponding author) Sahabat Morowali, Jl Yos Sudarso No. 36, Kolonodale, 94671, Central Sulawesi, Indonesia E-mail: gcbaker@bdg.centrin.net.id (or beakbird@hotmail.com)

Stuart Butchart Department of Zoology, Downing Street, Cambridge, CB2 3EJ, UK. E-mail: shmb1@cus.cam.ac.uk

Revised manuscript accepted for publication 6 March 2000 order to safeguard the maleo from further declines we recommend that the laws protecting the maleo and its habitat be strengthened as a matter of urgency and that long-term community conservation and environmental awareness projects be implemented. To achieve these goals we advocate the formation of a collaborative network of international NGOs, Indonesian conservationists, government departments and local communities.

Keywords Conservation, egg-harvesting, maleo, megapode, semi-captive breeding, Sulawesi, threats.

North Sulawesi and collated information from elsewhere on the island. In 1998, we surveyed 20 of the 83 sites listed by Argeloo (1994) in Central and South Sulawesi, and we located and surveyed an additional 43 previously unrecorded nesting grounds in this region (Butchart \& Baker, 2000). We estimated the global population for maleos to be $4000-7000$ breeding pairs (Butchart \& Baker, 2000). The total number of confirmed nesting grounds is 131 (Argeloo, 1994; Prawiradilaga, 1997; Baltzer, in litt.; Butchart \& Baker, 2000), of which 12 (9.2 per cent) are of unknown status. Of the 119 sites of known status, 42 sites ( 35.3 per cent) have already been abandoned, 38 (31.9 per cent) are severely threatened, 34 (28.6 percent) are threatened, and only five nesting grounds (4.2 per cent) are not yet threatened (see Table 1 for definitions of threat categories). In this paper we discuss the threats that have led to population declines and abandonment of nesting grounds, assess the relative merits of conservation strategies and make specific recommendations for the conservation of maleos.

\section{Methods}

The following analysis is based largely on data from 63 maleo nesting grounds in Central and South Sulawesi, which we surveyed in June-August and OctoberNovember 1998 (see Butchart \& Baker, 2000). Sites were categorized as coastal (within $100 \mathrm{~m}$ of the high-tide line) or inland (along river banks and at geothermal sites). At each nesting ground, we carried out semistructured interviews with local people (including eggcollectors, village heads, guides and forestry officials) in 
order to gather the following data: current and historical egg-harvests; numbers and origin of people collecting eggs; the nature of any traditional nesting ground management or controls over egg-collection; the protected status of surrounding habitat; and intensities of hunting or trapping of adult birds. All questions were open-ended, and were phrased to avoid simple yes/no answers (see Butchart \& Baker, 2000). On the basis of this information and data gathered from site surveys (Butchart \& Baker, 2000), we defined the conservation status of nesting grounds following the criteria used by Dekker (1990) and Argeloo (1994); see Table 1.

\section{Threats to the maleo}

\section{Habitat degradation}

Coastal nesting grounds have been more severely affected by habitat degradation than inland nesting grounds because development and population growth have been concentrated in lowland coastal areas (Watling, 1983; Dekker, 1990). Some coastal maleo nesting grounds have been lost through destruction of the site for road building, creation of artificial fish ponds and other developments. In addition, intensification of fishing (e.g. the use of dynamite) has increased disturbance even at previously isolated beaches. Thus, a significantly larger proportion of coastal than inland nesting grounds have been abandoned: 34 (45.3 per cent) of 75 coastal sites versus 8 (17.8 per cent) of 45 inland sites, $\chi^{2}=6.31, P<0.02$; Fig. 1 , Table 2 ).

Large swathes of habitat adjacent to the coast have been converted to cultivation, such as oil palm and coconut plantations, and this form of habitat degradation is increasing (Anon., 1998). Consequently, a significantly larger proportion of coastal than inland nesting grounds are now completely isolated from primary

Table 1 Criteria for assessment of conservation status of nesting grounds (after Dekker, 1990 and Argeloo, 1994)

\begin{tabular}{ll}
\hline Status & Criteria \\
\hline Abandoned & $\begin{array}{l}\text { No eggs currently laid at the nesting } \\
\text { ground } \\
\text { Only a few pairs make use of the ground } \\
\text { and may be expected to abandon it within } \\
\text { threatened }\end{array}$ \\
$\begin{array}{l}\text { the near future } \\
\text { Nesting ground is still used for egg-laying } \\
\text { by a considerable population of maleos, } \\
\text { but is not considered safe for the future } \\
\text { because of egg-collecting, adverse } \\
\text { developments in the area or both } \\
\text { Nesting ground still intact and freely } \\
\text { accessible to maleos, with egg-collecting } \\
\text { absent or at a low level }\end{array}$ \\
Not yet &
\end{tabular}

forest (23 (56.1 per cent) of 41 coastal sites versus 7 (19.4 per cent) of 36 inland sites, $\chi^{2}=6.56, P<0.02$; data from Argeloo, 1994; Butchart \& Baker, 2000)). Isolation of nesting grounds from foraging habitat is likely to have a detrimental effect on maleo populations (Dekker \& McGowan, 1995). Although adult birds can traverse degraded habitats, the survival of chicks is likely to be reduced where there is no intact forest connecting nesting grounds to suitable foraging habitat.

Both coastal and inland sites in lowland forest are suffering from the increasing human population in Sulawesi brought about by government-initiated transmigration programmes (Whitten et al., 1987; Potter \& Lee, 1998). Although the majority of Sulawesi's montane forest remains intact (Whitten et al., 1987; Collins ef al., 1991), clearance for cultivation, logging and mining activities is beginning to degrade these habitats. We found that many inland maleo nesting grounds are now increasingly threatened by such activities.

\section{Egg-harvesting}

Egg-harvesting is an integral part of Sulawesi's heritage (Argeloo \& Dekker, 1996), but only seven (16.6 per cent) of the 42 currently-used nesting grounds in Central and South Sulawesi are still managed by local laws or traditions. All seven are coastal sites, which are managed by either the forestry department or by small local communities. There is no evidence that harvesting at traditionally managed sites is sustainable, but these sites at least provide greater opportunities for community conservation initiatives because of the restricted access to the nesting ground. At all other sites, eggs are taken either regularly or opportunistically by seminomadic indigenous people and villagers collecting forest products or hunting in the vicinity of nesting grounds. Egg-harvesting is a particular problem in transmigration areas. All nesting grounds known to be within $5 \mathrm{~km}$ of transmigrant settlements had been abandoned $(n=5)$ or were considered to be severely threatened $(n=1)$. Unlike habitat degradation, the detrimental consequences of unsustainable egg-harvesting may not be apparent for several years because of the long life span of the maleo (over 30 years in captivity, D. Bruning, pers comm.).

As reported by Argeloo (1994), we found that opportunistic egg-harvesting by rattan-collectors is a significant threat to inland nesting grounds. In the past, rattan was collected from forest adjacent to villages, but increasing demands are forcing collectors to find more distant supplies. Recent studies in Lore Lindu, however, suggest that it may not be economically viable to collect more distant cane supplies and, as a result, rattan collection may decline over the next decade. 
Fig. 1 Map showing the distribution and conservation status of confirmed maleo nesting grounds in Sulawesi. Data are from Argeloo (1994), Prawiradilaga (1997), Baltzer (in litt.) and Butchart \& Baker (2000). Dotted lines indicate the approximate locations of Lore Lindu National Park and Morowali Nature Reserve.

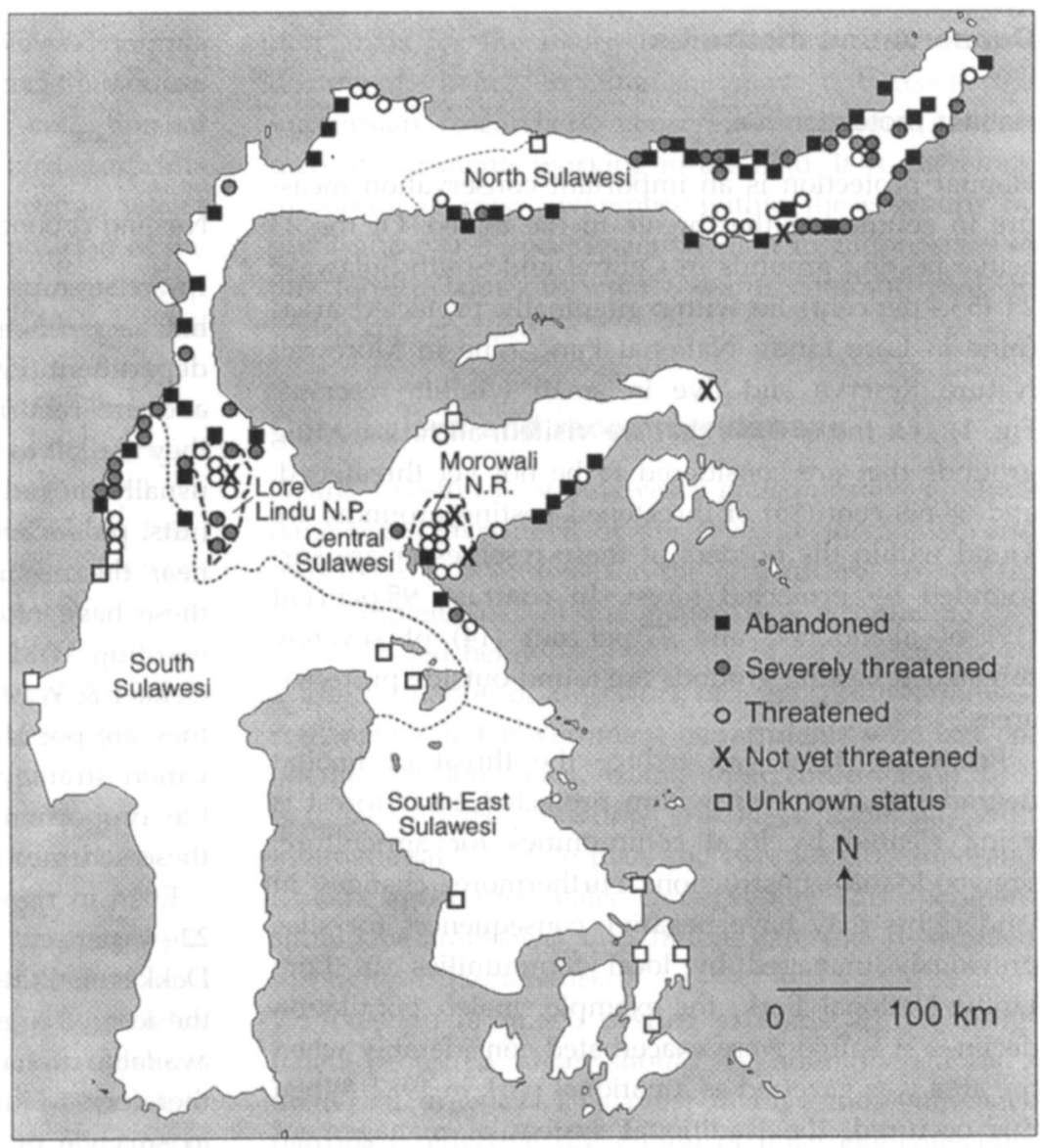

Table 2 Number of coastal and inland nesting grounds in each category of threat

\begin{tabular}{llllllr}
\hline & Unknown status & Abandoned & Severely threatened & Threatened & Not yet threatened & Total \\
\hline Coastal & 9 & $34(45.9)$ & $24(32.4)$ & $14(18.9)$ & $2(2.7)$ & 83 \\
Inland & 3 & $8(17.7)$ & $14(31.1)$ & $20(44.4)$ & $3(6.6)$ & 48 \\
Total & 12 & 42 & 38 & 34 & 5 & 131 \\
\hline
\end{tabular}

Data in parentheses represent the percentage of sites of known status. North Sulawesi data are from Argeloo (1994); Central and South Sulawesi data are from Prawiradilaga (1997), Baltzer (in litt.) and Butchart \& Baker (2000).

Nevertheless, rattan-collectors' trails make inland maleo nesting grounds more accessible to hunters and other villagers who collect eggs opportunistically. Such indirect consequences of rattan exploitation are likely to have more significant detrimental effects on fauna than the direct effects of habitat modification (S. Siebert, pers. comm.).

\section{Hunting}

Shooting, trapping and snaring of maleos at or adjacent to nesting grounds were reported at 12 sites $(27.9$ per cent of active sites) in Central and South Sulawesi. Communities with established egg-harvesting traditions generally outlaw the killing of adult maleos, but opportunistic hunting by villagers, transmigrants and nomadic communities probably occurs at most other sites. Although habitat degradation and over-collection of eggs are probably having the greatest detrimental effect on maleo populations, hunting in combination with these threats may have serious consequences for dwindling populations at the remaining active sites. 


\section{Conservation measures}

Habitat protection

Habitat protection is an important conservation measure in countering the threats to the maleo. Of the 43 active nesting grounds in Central and South Sulawesi, 23 (53.4 per cent) lie within nominally protected areas (nine in Lore Lindu National Park, nine in Morowali Nature Reserve and five in small wildlife reserves; Fig. 1). Of the 63 sites that we visited, all four nesting grounds that are considered to be not yet threatened, and 68 per cent (15) of threatened nesting grounds, are found within the borders of these reserves or are surrounded by protected forest. In contrast, 95 per cent (19) of abandoned and 77 percent (14) of severely threatened nesting grounds are found outside protected areas.

Protected status can reduce the threat of habitat degradation, but even within protected areas forest is being cleared by local communities for agriculture, firewood and construction. Furthermore, changes in land rights may have negative consequences for sites previously managed by local communities. In Lore Lindu National Park, for example, maleo population declines at Saluki were exacerbated considerably when the area was gazetted as a national park in 1982. When this occurred, the traditional system of management broke down and uncontrolled egg-collecting increased.

The Morowali Reserve supports 18-27 per cent of Sulawesi's maleo population (see Butchart \& Baker, 2000). Until recently there have been no roads within the reserve and access has been difficult. However, a road is currently under construction and there are plans to give Morowali national park status, which may make it more accessible to other communities. To maintain Morowali as a stronghold for maleos, and to improve protection of nesting grounds in Lore Lindu, we recommend strict management and patrolling by forest guards to enforce laws prohibiting habitat degradation and egg-collection. In order to achieve this, close collaboration between NGOs, forestry departments and communities is needed.

The preservation of corridors of forest between coastal nesting grounds and foraging areas in forest further inland may also reduce the threat of nesting grounds being abandoned. In Wosu, on the eastern coast of Central Sulawesi, local conservation groups and the forestry department have been negotiating with plantation companies to leave a corridor of forest, in the centre of a tract of land sold for clearance, to allow maleos to reach their nesting ground safely. This project is supported by the local people who have traditional controls over egg-harvesting, but who also support development of plantations because of their economic benefits to the village.

\section{Nesting ground management}

In an attempt to prevent uncontrolled egg-harvesting, hatchery schemes have been initiated by the forestry department. Eggs are excavated from nesting grounds and are reburied inside cages located nearby, where they are left to incubate. When the chicks hatch they are usually moved to a second cage where they are fed on nuts, pulses or rice for 1-7 days before being released near the nesting ground. Hatchery schemes such as these have often been recommended as a method of boosting wild maleo populations (MacKinnon, 1981; Dekker \& Wattel, 1987; Dekker \& McGowan, 1995) and they are popular in Indonesia as a high-profile conservation strategy. However, although they may reduce the proportion of eggs stolen from nesting grounds, these schemes have several serious disadvantages.

Even in rigorously controlled hatchery experiments, 22-49 per cent of eggs fail to hatch (MacKinnon, 1981; Dekker \& Wattel, 1987), and at poorly managed sites the loss of eggs is probably higher. There are no data available on natural hatching rates and it is impossible, therefore, to judge whether egg moving is detrimental to survival or not. In 1998, we found two hatcheries operating in Central Sulawesi. At Tanjung Matop, 56 per cent of 380 eggs hatched and were released, but these estimates may be inflated by the guard responsible for the programme. At Bakiriang, egg records were missing, but c. 50 percent of eggs were reported to hatch. Similar success rates were reported for hatcheries that had operated at Saluki and Taba. After hatching, the duration that chicks are usually held prior to release is probably detrimental to their survival. Maleo hatchlings are highly precocial and are able to fly and feed almost immediately after hatching (Dekker, 1990), so they should be released as soon as possible.

All hatchery schemes seem to suffer from inadequate management. Funding is seldom available to pay reliable guards, and eggs are often sold by the very people who are meant to be protecting them. Once hatcheries have been built, there is a lack of monitoring and little commitment to their maintenance. We suggest that the lack of regular evaluation and sustained commitment of resources and initiative to hatchery programmes since they were first recommended by MacKinnon (1981) means that they are unlikely to be the conservation panacea that they might at first have seemed. We recommend that these issues be addressed urgently by the programmes currently operating, and we do not advocate the initiation of new schemes. 
Nevertheless, nesting ground managers and guards have an important role to play in protecting nesting grounds and directly preventing illicit collection of eggs. For example, egg-collectors rely on bird footprints and disturbances in the sand to locate burrows where eggs have been laid, and to indicate the position of the egg. If such visual cues are removed by raking the top layer of sand across the nesting ground, burrows are more difficult to locate and eggs may be more likely to survive incubation in situ (G.C.B. \& S.H.M.B., pers. obs.). Managers can also improve the suitability of nesting grounds for maleos by clearing areas that have become overgrown with vegetation (MacKinnon, 1981; Dekker, 1990; Dekker \& McGowan, 1995). Dekker (1990) also recommended digging artificial burrows in order to provide more suitable nesting habitat. MacKinnon (1981) suggested the use of fencing to keep egg predators from maleo nesting grounds. Although both adults and hatchlings can fly, they often run when disturbed at nesting grounds. Fencing could therefore impair escape from predators, so we caution the use of artificial barriers at nesting grounds.

Although the economic crisis in Indonesia has put further pressures on natural resources, NGOs and local communities have become more vocal about their rights to manage local ecosystems. Community management of resources may be the most successful conservation strategy in the long term. A model community conservation programme was being tested at the maleo nesting ground in Wosu, Central Sulawesi, and some controls had been put in place. However, the project was recently disbanded after members of the NGO running the project were held hostage over local political issues. The current political instability of Indonesia is obstructing conservation effort and future community projects need to be developed with a deep regard for local politics if they are to be successful.

\section{Education}

The maleo is the official symbol of Central Sulawesi, and there are maleo monuments and namesakes throughout the island, so the species is extremely well known. It is, therefore, an extraordinarily suitable flagship species. However, there is widespread ignorance regarding the maleo's endemism to Sulawesi, its conservation status, the extent of population declines, the degree to which maleos are threatened by habitat degradation and egg-collecting, and the urgency of protecting this species. Nevertheless, the people of Sulawesi show a sincere interest in the plight of the maleo, and conservation initiatives should capitalize on this fact. The IUCN action plan for megapode conservation 2000-2004 (Dekker et al., in press) highlights conserva- tion goals for the maleo and other megapodes. This document, being in English, may not reach the Indonesian researchers, conservationists and government departments working in the field. It is, therefore, important to raise awareness within these groups by publication of a specific action plan in Indonesian, so that local groups can work towards common goals in maleo conservation.

\section{Conclusions and recommendations}

Nearly two-thirds of Sulawesi's maleo nesting grounds have been abandoned or are severely threatened and thus likely to abandoned in the near future. To prevent the complete loss of the maleo, we recommend the actions listed below.

1 The formation of a network of local conservationists, researchers and government departments who can cooperate on long-term, island-wide conservation programmes. This network should collaborate with international NGOs to plan and execute a detailed and realistic agenda for maleo conservation. This document should be translated into Indonesian and distributed throughout the network.

2 Protection of maleo nesting grounds within designated protected areas should be strengthened as a matter of urgency. This must involve more intensive patrolling, effective prevention of illicit egg-collecting, habitat degradation and hunting, and strict enforcement of punishment for offenders. Close collaboration between conservation NGOs and the forest department, and effective management of forest officers are required in order to achieve these results.

3 Forest corridors linking coastal maleo nesting grounds to forested areas inland should be developed and strictly protected in collaboration with local communities.

4 Nesting grounds that still support good maleo populations but that are threatened by human activities and are still officially unprotected should be gazetted as protected areas as a matter of priority.

5 Intensive environmental awareness campaigns should be initiated. As a priority these should focus on communities in the vicinity of maleo nesting grounds. Such programmes must communicate the uniqueness and endemism of maleos, their current poor and deteriorating conservation status, the importance of eggcollecting and habitat degradation in reducing populations, and the global impact of local action in controlling these threats.

6 Politically sensitive case-specific schemes for community-managed sustainable harvesting of maleo eggs and protection of nesting grounds should be implemented at a grass roots level, with the support and 
co-operation of international agencies and government departments.

7 The use of artificial hatcheries should be continued only if effective management can be developed, incorporating regular monitoring and sustained commitment of resources and local political support. We do not advocate the initiation of further hatchery schemes.

8 Such efforts to conserve maleos should be prioritized at sites that still support significant maleo populations in areas of good habitat and that are less threatened by egg-collection, habitat degradation and hunting. Elsewhere, we have identified eight such priority areas for Central Sulawesi (Butchart \& Baker, 2000). Up-to-date priorities for sites in North Sulawesi need to be identified, and surveys of southeast Sulawesi are required.

\section{Acknowledgements}

We gratefully thank our colleagues from Yayasan Jambata, Yayasan Maleo Indonesia and Sahabat Morowali with whom we carried out these surveys, and without whom this fieldwork could not have taken place: Buttu Ma'dika, Zarlif, Rizkan Intjehatu, Mohammad Yammin, Lukman, Mohammad Irfan, Idris Tinulele, Fachry Nur Mallo, Yusran Zainudin, Erno Siara, Yos Tumakaka, Atha Mahmud, Jamal Beddu and Rustam Semma. For funding, support and assistance, we are grateful to The Netherlands Foundation for International Nature Protection, Stiftung Avifauna Protecta, British Airways Assisting Conservation, NRM2/EPIQ through the Forum Kemitraan Taman Nasional Lore Lindu, The World Pheasant Association, and The Nature Conservancy. Many people welcomed us into their homes, guided us in the field, or provided advice and assistance; they are acknowledged in our field reports (Baker 1998; Butchart et al., 1998), which are available from the authors. We are particularly grateful to Duncan and Rita Neville, Jabar and Ibu Lahadji, René Dekker, Marc Argeloo, Hendra Hendarin and Don Baker, and we thank Nat Seddon, Nigel Collar and an anonymous referee for comments on the text.

\section{References}

Anon. (1998) Palm Oil Expands, Farmers Lose Out. Down to Earth Report No. 36. Unpublished.
Argeloo, M. (1994) The maleo Macrocephalon maleo: new information on the distribution and status of Sulawesi's endemic megapode. Bird Conservation hiternational, 4 , 383-393.

Argeloo, M. \& Dekker, R.W.R.J. (1996) Exploitation of megapode eggs in Indonesia: the role of traditional methods in the conservation of megapodes. Oryx, 30, $59-64$.

Baker, G.C. (1998) Maleo Survey and Education Project Phase One. Unpublished report.

Butchart, S.H.M. \& Baker, G.C. (2000) Priority sites for conservation of maleos (Macrocephalon malev) in central Sulawesi. Biological Conservation, 94, 79-91.

Butchart, S.H.M., Ma'dika, B., Zarlif, Yamin, M., Lukman, Irfan, M., Tinulele, 1., Intjehatu, R. \& Mallo, F.N. (1998) The Status of the Maleo in Western Central Sulnowesi. Unpublished report.

Coates, B.J., Bishop, K.D. \& Gardner, D. (1997) A Guidte to the Birds of Wallacea: Sulawesi, The Molucas and Lesser Sunda islands, Indonesia. Dove Publications, Alderley, Australia.

Collar, N.J., Crosby, M.J. \& Stattersfield, A.J. (1994) Birds to Watch 2. The World List of Threatened Birds. BirdLife Conservation Series No. 4. BirdLife International, Cambridge.

Collins, N.M., Sayer, J.A. \& Whitmore, T.C. (1991) Conservation Atlas of Tropical Forests: Asin and Pacific. Macmillan, London.

Dekker, R.W.R.J. (1990) The distribution and status of nesting grounds of the maleo Macrocephalon maleo in Sulawesi, Indonesia. Biological Conservation, 51, 139-150.

Dekker, R.W.R.J. \& McGowan, P.J.K. (1995) Megapotes: An Action Plan for their Conservation 1995-1999. IUCN, Gland, Switzerland.

Dekker, R.W.R.J. \& Wattel, J. (1987) Egg and image: new and traditional uses for the maleo Macroceplalon maleo. In The Value of Birds. ICBP Technical Publication No. 6 (eds A. W. Diamond and F. Fillon), pp. 83-87. International Council for Bird Preservation, Cambridge.

Dekker, R.W.R.J., Fuller, R. \& Baker, G.C. (in press) Megapodes: An Action Plan for their Conservation 2000-2004. IUCN, Gland, Switzerland.

Jones, D.N., Dekker, R.W.R.J. \& Roselaar, C.S. (1995) The Megapodes. Oxford University Press, Oxford.

MacKinnon, J. (1981) Methods for the conservation of maleo birds, Macrocephalon maleo, on the island of Sulawesi, Indonesia. Biological Conservation, 20, 183-193.

Potter, L. \& Lee, J. (1998) Tree Planting in Indonesia: Trends, Impacts and Directions. Unpublished report. Department of Geography, University of Adelaide, Australia.

Prawiradilaga, D.M. (1997) The maleo Macrocephalon maleo on Buton. Bulletin of the British Ornithologists' Club, 117, 237.

Watling, D. (1983) Ornithological notes from Sulawesi. Emu, 83, 247-261.

Whitten, A.J., Mustafa, M. \& Henderson, G.S. (1987) The Ecology of Sulawesi. Gadjah Mada University Press, Yogyakarta, Indonesia. 


\section{Biographical sketches}

Dr Gillian Baker is an ecologist working with Sahabat Morowali, a conservation NGO in Sulawesi, Indonesia. Her predominate conservation interest is in megapodes, especially within Indonesia. Her research interests are broad, including megapode ecology and behaviour, molecular identification of protists and bacteria, and competition amongst larval anuran assemblages.

Dr Stuart Butchart is a research fellow at the Department of Zoology, University of Cambridge, UK. His conservation interests have encompassed surveys and status assessments for threatened birds and mammals in Indonesia, Paraguay, Peru and Madagascar. His main research interests lie within behavioural ecology, including shorebird mating systems and co-evolution between brood parasitic cuckoos and their hosts. 